\title{
Possibility of wine production from karanda (Carissa carandas L.) fruit
}

\author{
Nguyen Phuoc Minh \\ Institute of Applied Technology, Thu Dau Mot University, Binh Duong Province, Vietnam \\ *Email: nguyenphuocminh@tdmu.edu.vn
}

ARTICLE HISTORY

Received: 03 June 2021

Accepted: 25 June 2021

Available online: 11 July 2021

\section{KEYWORDS}

ethanol

fermentation

phenolic content

wine
ABSTRACT

Karanda (Carissa carandas L.) is an underutilized fruit with plenty therapeutic and functional properties. In fermentation, yeast metabolites soluble solids in fruit juice to produce energy, ethanol and carbon dioxide. The present research aimed to examine various parameters such as temperature, $\mathrm{pH}$, sugar addition and inoculum size in the primary fermentation, and aging time in storage affecting to karanda wine quality. This research was conducted from 2019 to 2020. Results showed that supplementation of sugar $9 \%, \mathrm{pH} 3.6$, temperature $28{ }^{\circ} \mathrm{C}$, inoculum size $14 \%$ and aging in 10 weeks, karanda wine obtained high ethanol content $(8.19 \pm 0.02 \% \mathrm{v} / \mathrm{v})$, total phenolic content $(184.32 \pm 1.17 \mathrm{mg}$ $\mathrm{GAE} / 100 \mathrm{~g}$ ) and overall acceptability (8.01 \pm 0.02$)$. Wine from this valuable karanda fruit would be beneficial for health by moderate consumption.

\section{Introduction}

Ethanol is one of the main constituents in wine production from fruit juice under dynamic reaction of Saccharomyces cerevisiae (1). Polyphenols, organic acids, mineral salts, pectins and volatiles are also important in improving functional and organoleptic properties of wine $(2,3)$. Temperature, $\mathrm{pH}$, soluble solid content, yeast inoculum size, secondary fermentation duration are vital variables greatly influencing to the growth and proliferation of yeast to synthesize beneficial component in wine (4).

Karanda (Carissa carandas L.) is an exploited fruit closely related to Carissa spinarum. It contains a huge amount of vitamins, phenolics, minerals (5-7). It has been used as folk medicine with various therapeutic properties like antidiabetic, antimicrobial, cytotoxicity, hepatoprotective, anti-inflammatory (812). It's commonly converted to jam, jellies and pickles (13). There has been a trend in doing research related to wine production from different varieties of fruit source $(14,15)$. The fermentation was influenced by numerous variables such as the initial soluble solid, yeast inoculation ratio, and fermentation duration (16). The main objective of our study was to optimize the fermentation parameters such as temperature, $\mathrm{pH}$, sugar addition, inoculum size and aging time to achieve good quality wine with respect to high ethanol content, total phenolic content and overall acceptability.

\section{Materials and Methods}

\section{Material}

Carissa carandas L. fruits were collected from the gardens in Soc Trang province, Vietnam. They were cleaned under tap water to remove debris and other matters. Saccharomyces cerevisiae was supplied from Pasteur Institute, Ho Chi Minh city, Vietnam. It was cultured in stocking pepton media before inoculating to must fermentation. Chemical reagents such as $\mathrm{NaHCO}_{3}$, ascorbic acid, Folin-Ciocalteu reagent, standard gallic acid were all analytical grade $(>99 \%$ in purity) purchased from Merck (Darmstadt, Germany).

\section{Experiments}

Seeds were removed from the fruits by hand. Seedless fruits were sanitized with peracetic acid $50 \mathrm{ppm}$ to retard the growth of wild microorganism.

\section{Experiment \#1}

\section{Effect of temperature to wine quality attributes}

The preliminary treated fruits were added with $5 \%$ sugar, initial pH 3.8 adjusted by $\mathrm{NaHCO}_{3}$ or ascorbic acid, yeast inoculum size $8 \%$ (12 log $\mathrm{cfu} / \mathrm{ml})$. The

(c) Minh (2021). This is an open-access article distributed under the terms of the Creative Commons Attribution License, which permits unrestricted use, distribution and reproduction in any medium, provided the original author and source are credited (https://creativecommons.org/licenses/by/4.0/). 
main fermentation was performed in 15 days at different temperatures $\left(24,26,28,30,32{ }^{\circ} \mathrm{C}\right)$. Secondary fermentation continued for 4 weeks at cool storage $25{ }^{\circ} \mathrm{C}$ as ageing. Turbidity in wine was overcome by flocculation with $0.5 \%$ gelatin and filtered through Whatman paper No. 4. Wine was ready for evaluation of ethanol content $(\% \mathrm{v} / \mathrm{v})$, total phenolic content (mg GAE/100g) and overall acceptability.

\section{Experiment \#2}

\section{Effect of pH to wine quality attributes}

The preliminary treated fruits were added with 5\% sugar, initial $\mathrm{pH}$ adjusted to different values (3.4, $3.5,3.6,3.7,3.8$ ) by $\mathrm{NaHCO}_{3}$ or ascorbic acid, yeast inoculum size $8 \%(12 \log \mathrm{cfu} / \mathrm{ml})$. The main fermentation was performed in 15 days at temperature $28{ }^{\circ} \mathrm{C}$. Secondary fermentation continued for 4 weeks at cool storage $25{ }^{\circ} \mathrm{C}$ as ageing. Turbidity in wine was overcome by flocculation with $0.5 \%$ gelatin and filtered through Whatman paper No. 4. Wine was ready for evaluation of ethanol content $(\% \mathrm{v} / \mathrm{v})$, total phenolic content (mg GAE/100 gm) and overall acceptability.

\section{Experiment \#3}

\section{Effect of sugar addition to wine quality attributes}

The preliminary treated fruits were added with sugar in different amounts $(5,7,9,11,13 \%)$, initial $\mathrm{pH}$ adjusted to 3.6 by $\mathrm{NaHCO}_{3}$ or ascorbic acid, yeast inoculum size $8 \%(12 \mathrm{log} \mathrm{cfu} / \mathrm{ml})$. The main fermentation was performed in 15 days at temperature $28{ }^{\circ} \mathrm{C}$. Secondary fermentation continued for 4 weeks at cool storage $25{ }^{\circ} \mathrm{C}$ as ageing. Turbidity in wine was overcome by flocculation with $0.5 \%$ gelatin and filtered through Whatman paper No. 4. Wine was ready for evaluation of ethanol content $(\% \mathrm{v} / \mathrm{v})$, total phenolic content (mg GAE/100 gm) and overall acceptability.

\section{Experiment \#4}

Effect of inoculum size to wine quality attributes

The preliminary treated fruits were added with sugar $9 \%$, initial $\mathrm{pH}$ adjusted to 3.6 by $\mathrm{NaHCO}_{3}$ or ascorbic acid, different yeast inoculum sizes 8,10 , $12,14,16 \%$ (12 log $\mathrm{cfu} / \mathrm{ml})$. The main fermentation was performed in 15 days at temperature $28{ }^{\circ} \mathrm{C}$. Secondary fermentation continued for 4 weeks at cool storage $25{ }^{\circ} \mathrm{C}$ as ageing. Turbidity in wine was overcome by flocculation with $0.5 \%$ gelatin and filtered through Whatman paper No. 4. Wine was ready for evaluation of ethanol content $(\% \mathrm{v} / \mathrm{v})$, total phenolic content (mg GAE/100 gm) and overall acceptability.

\section{Experiment \#5}

\section{Effect of aging time to wine quality}

The preliminary treated fruits were added with sugar $9 \%$, initial pH adjusted to 3.6 by $\mathrm{NaHCO}_{3}$ or ascorbic acid, yeast inoculum sizes $14 \%$ (12 log $\mathrm{cfu} / \mathrm{ml})$. The main fermentation was performed in 15 days at temperature $28{ }^{\circ} \mathrm{C}$. Secondary fermentation continued for different durations $(4,6,8,10,12$ weeks) at cool storage $25{ }^{\circ} \mathrm{C}$ as ageing. Turbidity in wine was overcome by flocculation with $0.5 \%$ gelatin and filtered through Whatman paper No. 4. Wine was ready for evaluation of ethanol content $(\% \mathrm{v} / \mathrm{v})$, total phenolic content (mg GAE/100 gm) and overall acceptability.

\section{Physicochemical evaluation}

Ethanol content (\% v/v) was determined by capillary gas chromatography using megapore polar column (17). Total phenolic content (mg GAE/100 gm) was estimated by Folin-Ciocalteu reagent assay (18). Overall acceptability was evaluated by a group of panelists using 9-point Hedonic scale.

\section{Statistical summary}

The demonstrations were prepared as 3 replicates for various sample groups. The values were expressed as mean \pm standard deviation. Statistical summary was done using Statgraphics version XVI.

\section{Results and Discussion \\ Effect of Fermentation Temperature to Karanda Wine Quality Attributes}

Fermentation temperature has been greatly affected the growth and proliferation of yeast hence, it directly influenced the ethanol formation, total phenolic content and sensory characteristics. Influence of fermentation temperature to ethanol formation $(\% \mathrm{v} / \mathrm{v})$, total phenolic (mg GAE/100 ml) and overall acceptability of Carissa carandas wine was presented in Table 1 . When temperature increased from 24 to $28{ }^{\circ} \mathrm{C}$, ethanol formation $(3.27 \pm 0.00$ to $4.87 \pm 0.02 \% \mathrm{v} / \mathrm{v})$, total phenolic $(124.08 \pm 2.19$ to $146.25 \pm 1.38 \mathrm{mg}$ GAE$/ 100 \mathrm{ml})$ and overall acceptability $(3.56 \pm 0.02$ to $4.69 \pm 0.03)$ accumulated respectively. However, at temperature 30 or $32{ }^{\circ} \mathrm{C}$, these parameters degraded significantly. Therefore, $28{ }^{\circ} \mathrm{C}$ was optimal for Carissa carandas wine fermentation. Similarly, wine prepared from $C$. spinarum fruit at the fermentation temperature of $25{ }^{\circ} \mathrm{C}$, resulted to have $8.3 \%(\mathrm{v} / \mathrm{v})$ of ethanol, $134.9 \mathrm{mg} \mathrm{GAE} / 100 \mathrm{ml}$ of total phenolic content and 7.2 out of 10 in sensory attributes (19). High fermentation temperature

Table 1. Effect of fermentation temperature to wine quality attributes

\begin{tabular}{lcccc}
\hline $\begin{array}{c}\text { Fermentation temparature } \\
\left({ }^{\circ} \mathbf{C}\right)\end{array}$ & $\mathbf{2 4}$ & $\mathbf{2 6}$ & $\mathbf{2 8}$ & $\mathbf{3 2}$ \\
\hline Ethanol (\% v/v) & $3.27 \pm 0.00^{\mathrm{c}}$ & $3.95 \pm 0.01^{\mathrm{bc}}$ & $4.87 \pm 0.02^{\mathrm{a}}$ & $4.52 \pm 0.00^{\mathrm{ab}}$ \\
\hline $\begin{array}{l}\text { Total phenolic content } \\
(\mathrm{mg} \mathrm{GAE} / 100 \mathrm{ml})\end{array}$ & $124.08 \pm 2.19^{\mathrm{c}}$ & $130.18 \pm 1.63^{\mathrm{bc}}$ & $146.25 \pm 1.38^{\mathrm{a}}$ & $140.73 \pm 1.27^{\mathrm{ab}}$ \\
\hline Overall acceptability & $3.56 \pm 0.02^{\mathrm{c}}$ & $3.75 \pm 0.01^{\mathrm{bc}}$ & $4.69 \pm 0.03^{\mathrm{a}}$ & $4.22 \pm 0.00^{\mathrm{ab}}$ \\
\hline
\end{tabular}

Figures are the mean of three replications; Figures in column followed by the same letter/s are not differed significantly $(\alpha=P=0.05)$. 
Table 2. Effect of $\mathrm{pH}$ in fermentation to wine quality attributes

\begin{tabular}{|c|c|c|c|c|c|}
\hline pH of fermentation & 3.4 & 3.5 & 3.6 & 3.7 & 3.8 \\
\hline Ethanol (\% v/v) & $3.81 \pm 0.02^{\mathrm{c}}$ & $4.25 \pm 0.03^{\mathrm{bc}}$ & $6.43 \pm 0.01^{\mathrm{a}}$ & $5.14 \pm 0.03^{\mathrm{ab}}$ & $4.87 \pm 0.02^{b}$ \\
\hline $\begin{array}{l}\text { Total phenolic content } \\
(\mathrm{mg} \text { GAE } / 100 \mathrm{ml})\end{array}$ & $137.53 \pm 1.42^{c}$ & $141.06 \pm 1.17^{\mathrm{bc}}$ & $165.02 \pm 1.15^{\mathrm{a}}$ & $159.34 \pm 1.19^{\mathrm{ab}}$ & $146.25 \pm 1.38^{b}$ \\
\hline Overall acceptability & $4.01 \pm 0.03^{c}$ & $4.24 \pm 0.00^{\mathrm{bc}}$ & $5.26 \pm 0.02^{\mathrm{a}}$ & $4.95 \pm 0.03^{\mathrm{ab}}$ & $4.69 \pm 0.03^{b}$ \\
\hline
\end{tabular}

Figures are the mean of three replications; Figures in column followed by the same letter/s are not differed significantly $(\alpha=P=0.05)$.

may induce to much more glycerol and higher alcohols. $22.3{ }^{\circ} \mathrm{C}$ was appropriate for mango wine fermentation (20). For guava wine production, 25 ${ }^{\circ} \mathrm{C}$ was found to be suitable (21).

\section{Influence of $\mathrm{pH}$ to Karanda Wine Quality Attributes}

$\mathrm{pH}$ is a major variable greatly affecting to the yeast proliferation and sensory quality of wine (4). Effect of $\mathrm{pH}$ to ethanol formation (\% v/v), total phenolic content (mg GAE/100 ml) and overall acceptability of Carissa carandas wine was presented in Table 2. Among different $\mathrm{pH}$ values (3.4-3.8), $\mathrm{pH} 3.6$ revealed the highest ethanol content $(6.43 \pm 0.01 \%$ $\mathrm{v} / \mathrm{v})$, total phenolic content $(165.02 \pm 1.15 \mathrm{mg}$ GAE/100 ml) and overall acceptability $(5.26 \pm 0.02)$ of Carissa carandas wine. In another report, winemaking prepared from $C$. spinarum fruit at $\mathrm{pH}$ of 3.5 resulted to $8.3 \%(\mathrm{v} / \mathrm{v})$ of ethanol, $134.9 \mathrm{mg}$ GAE/100 ml of total phenolic content and 7.2 out of 10 in sensory attributes (19). $\mathrm{pH} 2.47 \pm 0.06$ was ideal for karanda wine fermentation (22). Effect of $\mathrm{pH}$ on different kinds fruit wine (mango 3.8, guava 3.5 and plum 3.0) was reported such as $(20,21,23)$.

\section{Impact of Sugar Addition to Karanda Wine Quality Attributes}

Karanda had low total soluble solid. It's necessary to increase the soluble solid content of initial must to produce more alcohol. However, too much sugar creating osmotic pressure difference also retarded the growth, performance and viability of yeast, directly affecting to fermentation efficiency to release ethanol $(24,25)$. Effect of sugar supplementation to ethanol formation ( $\% \mathrm{v} / \mathrm{v})$, total phenolic content (mg GAE/100 ml) and overall acceptability of Carissa carandas wine was presented in Table 3. By different percentages of sugar addition (5-13 \%), 9\% sugar resulted the highest ethanol content $(7.25 \pm 0.03 \% \mathrm{v} / \mathrm{v})$, total phenolic $(186.23 \pm 1.04 \mathrm{mg} \mathrm{GAE} / 100 \mathrm{ml})$ and overall acceptability $(6.72 \pm 0.03)$. In one report, karanda juice supplemented with sugar to $24^{\circ} \mathrm{Brix}$ before fermentation resulted the total phenolic content $746.64 \pm 3.10 \mathrm{mg}$ GAE$/ 100 \mathrm{ml}$, ethanol $12.50 \pm 0.35 \%$ (22). Total phenolics $5.31 \pm 0.21 \mathrm{mg} \mathrm{TAE} / \mathrm{gm}$ was noticed on $C$. spinarum fruits (26). The initial soluble solid $18{ }^{\circ}$ Brix in juice was beneficial for dragon wine production to obtain $3.54 \% \mathrm{v} / \mathrm{v}$ ethanol (16).

\section{Effect of Inoculum Size to Karanda Wine Quality Attributes}

Influence of inoculum size to ethanol formation (\% $\mathrm{v} / \mathrm{v})$, total phenolic (mg GAE/100 ml) and overall acceptability of Carissa carandas wine was presented in Table 4. There was significant difference of quality indicators by varied inoculum size from $8-14 \%$. At $14 \%$ and $16 \%$, there was not significant difference of ethanol, total phenolic content and sensory attributes. Inoculum size 14\% was optimal to achieve the highest ethanol $(8.03 \pm 0.03 \% \mathrm{v} / \mathrm{v})$, total phenolic content $(201.03 \pm 1.26 \mathrm{mg} \mathrm{GAE} / 100 \mathrm{ml})$ and overall acceptability $(7.13 \pm 0.03)$ of Carissa carandas wine. Yeast greatly affected to the character and aroma of wine (27). In theory, the higher inoculum size implemented the higher ethanol content obtained. Wine prepared from $C$. spinarum fruit at inoculum size of $10 \%(\mathrm{v} / \mathrm{v})$ resulted to $8.3 \%(\mathrm{v} / \mathrm{v})$ of ethanol, $134.9 \mathrm{mg} \mathrm{GAE} / 100 \mathrm{ml}$ of total phenolic and 7.2 out of 10 in sensory attributes (19). Inoculum size of $11.9 \%$ was optimal for mango wine fermentation (20). Inoculum size of $12 \%$ was appropriate for guava wine production (21). Accumulation of high ethanol content limited yeast viability and growth (28). $2 \% \mathrm{v} / \mathrm{v}$ of the supplemented yeast inoculation size was optimal for dragon wine fermentation to obtain $3.54 \% \mathrm{v} / \mathrm{v}$ ethanol and $14.6^{\circ} \mathrm{Brix}$ residual sugar (16).

Table 3. Effect of sugar addition to wine quality attributes

\begin{tabular}{lccccc}
\hline Sugar addition (\%) & $\mathbf{5}$ & $\mathbf{7}$ & $\mathbf{9}$ & $\mathbf{1 1}$ & $\mathbf{1 3}$ \\
\hline Ethanol (\% v/v) & $6.43 \pm 0.01^{\mathrm{c}}$ & $6.79 \pm 0.02^{\mathrm{bc}}$ & $7.25 \pm 0.03^{\mathrm{a}}$ & $7.01 \pm 0.01^{\mathrm{ab}}$ & $6.86 \pm 0.03^{\mathrm{b}}$ \\
\hline $\begin{array}{l}\text { Total phenolic content } \\
\text { (mg GAE/100 ml) }\end{array}$ & $165.02 \pm 1.15^{\mathrm{c}}$ & $171.14 \pm 1.29^{\mathrm{bc}}$ & $186.23 \pm 1.04^{\mathrm{a}}$ & $180.37 \pm 1.03^{\mathrm{ab}}$ & $176.49 \pm 1.09^{\mathrm{b}}$ \\
\hline Overall acceptability & $5.26 \pm 0.02^{\mathrm{c}}$ & $5.53 \pm 0.03^{\mathrm{bc}}$ & $6.72 \pm 0.03^{\mathrm{a}}$ & $6.15 \pm 0.00^{\mathrm{ab}}$ & $5.89 \pm 0.02^{\mathrm{b}}$ \\
\hline
\end{tabular}

Figures are the mean of three replications; Figures in column followed by the same letter/s are not differed significantly $(\alpha=\mathrm{P}=0.05)$.

Table 4. Effect of inoculum size to wine quality attributes

\begin{tabular}{lccccc}
\hline Inoculum size (\%) & $\mathbf{8}$ & $\mathbf{1 0}$ & $\mathbf{1 2}$ & $\mathbf{1 4}$ & $\mathbf{1 6}$ \\
\hline Ethanol (\% v/v) & $7.25 \pm 0.03^{\mathrm{c}}$ & $7.69 \pm 0.00^{\mathrm{b}}$ & $7.91 \pm 0.02^{\mathrm{ab}}$ & $8.03 \pm 0.03^{\mathrm{a}}$ & $8.07 \pm 0.02^{\mathrm{a}}$ \\
\hline $\begin{array}{l}\text { Total phenolic content } \\
\text { (mg GAE/100 ml) }\end{array}$ & $186.23 \pm 1.04^{\mathrm{c}}$ & $194.17 \pm 1.04^{\mathrm{b}}$ & $197.05 \pm 1.11^{\mathrm{ab}}$ & $201.03 \pm 1.26^{\mathrm{a}}$ & $202.14 \pm 1.12^{\mathrm{a}}$ \\
\hline Overall acceptability & $6.72 \pm 0.03^{\mathrm{c}}$ & $6.95 \pm 0.01^{\mathrm{b}}$ & $7.06 \pm 0.02^{\mathrm{ab}}$ & $7.13 \pm 0.03^{\mathrm{a}}$ & $7.15 \pm 0.00^{\mathrm{a}}$ \\
\hline
\end{tabular}

Figures are the mean of three replications; Figures in column followed by the same letter/s are not differed significantly $(\alpha=\mathrm{P}=0.05)$. 
Table 5. Effect of aging time to wine quality attributes

\begin{tabular}{|c|c|c|c|c|c|}
\hline Aging time (weeks) & 4 & 6 & 8 & 10 & 12 \\
\hline Ethanol (\% v/v) & $8.03 \pm 0.03^{b}$ & $8.09 \pm 0.01^{\mathrm{ab}}$ & $8.13 \pm 0.00^{\mathrm{ab}}$ & $8.19 \pm 0.02^{\mathrm{a}}$ & $8.20 \pm 0.03^{\mathrm{a}}$ \\
\hline $\begin{array}{l}\text { Total phenolic content } \\
(\mathrm{mg} \text { GAE} / 100 \mathrm{ml})\end{array}$ & $201.03 \pm 1.26^{\mathrm{a}}$ & $197.68 \pm 1.15^{\mathrm{ab}}$ & $192.07 \pm 1.54^{\mathrm{b}}$ & $184.32 \pm 1.17^{\mathrm{bc}}$ & $176.92 \pm 1.04^{\mathrm{c}}$ \\
\hline Overall acceptability & $7.13 \pm 0.03^{c}$ & $7.52 \pm 0.03^{\mathrm{bc}}$ & $7.89 \pm 0.01^{\mathrm{b}}$ & $8.01 \pm 0.02^{\mathrm{ab}}$ & $8.29 \pm 0.03^{\mathrm{a}}$ \\
\hline
\end{tabular}

Figures are the mean of three replications; Figures in column followed by the same letter/s are not differed significantly $(\alpha=\mathrm{P}=0.05)$

\section{Effect of Aging Time to Karanda Wine Quality Attributes}

Effect of aging time to Carissa carandas wine quality was presented in Table 5. There were not much changes of ethanol content from 4 to 12 weeks of storage. Total phenolic content decreased slightly from 4-12 weeks. Meanwhile, overall acceptability improved greatly after 10 or 12 weeks. Aging in 10 weeks resulted Carissa carandas wine with ethanol $(8.19 \pm 0.02 \% \mathrm{v} / \mathrm{v})$, total phenolic $(184.32 \pm 1.17 \mathrm{mg}$ GAE/100 gm), overall acceptability $(8.01 \pm 0.02)$. In the present study, the main fermentation time lasted 15 days and secondary period was 10 weeks. In another research, karanda fruit was fermented by Saccharomyces cerevisiae in 22 days to release ethanol (22). Fermentation for $44 \mathrm{hrs}$ was enough for the dragon wine fermentation to obtain $3.54 \% \mathrm{v} / \mathrm{v}$ ethanol and $14.6{ }^{\circ}$ Brix residual sugar (16). A remarkable degradation of the total phenolic content during fermentation could be due to the adsorption of phenolics onto yeast cell wall as well as condensation and polymerization (3). However, several studies proved that bioactive substances were formed in wine during fermentation $(29,30)$.

\section{Conclusion}

Wine from fruits has multifunctional health benefits as a common beverage being enjoyed widely. Carissa carandas L. (Karanda) fruit contains numerous vitamins, minerals and soluble solids essential to yeast proliferation and performance. The present study verified different aspects influencing to karanda wine quality. With supplemented sugar $9 \%$, $\mathrm{pH}$ 3.6, temperature $28{ }^{\circ} \mathrm{C}$, inoculum size $14 \%$ and aging 10 weeks, karanda wine obained high ethanol content, total phenolic content and sensory attribute. By diversifying processing products from karanda fruit, added value of this fruit could be improved. Farmer would have more chance to escape hunger and poverty in cultivation of this plant.

\section{Acknowledgements}

We acknowledge the financial support for the publication provided by Thu Dau Mot University, Binh Duong province, Vietnam.

\section{Authors' contributions}

Nguyen Phuoc Minh arranged the experiments and also wrote the manuscript.

\section{Conflict of interests}

The author strongly confirm that this research was conducted with no conflict of interest.

\section{References}

1. Mundaragi A and Thangadurai D. Process optimization, physicochemical characterization and antioxidant potential of novel wine from an underutilized fruit Carissa spinarum L. (Apocynaceae). Food Science and Technology. 2017;38:1-6. https://doi.org/10.1590/1678-457X.06417

2. Conde C, Silva P, Fontes N, Dias A, Tavares RM, Sousa M, Agasse A, Delrot S, Geros H. Biochemical changes throughout grape berry development and fruit and wine quality. Global Science Books. 2006;1:1-22.

3. Mena P, Girones-Vilaplana A, Marti N, Garcia-Viguera C. Pomegranate varietal wines: Phytochemical composition and quality parameters. Food Chemistry. 2012;133:108-15. http:// dx.doi.org/10.1016/j.foodchem.2011.12.079

4. Arroyo-Lopez FN, Orlic S, Querol A, Barrio E. Effects of temperature, $\mathrm{pH}$ and sugar concentration on the growth parameters of Saccharomyces cerevisiae, S. kudriavzevii and their interspecific hybrid. International Journal of Food Microbiology.

http://dx.doi.org/10.1016/j.ijfoodmicro.2009.01.035

5. Singh S, Singh AK, Meghwal P, Singh A, Swamy GSK. Koranda. In: Ghos SN ed. Tropical and sub tropical fruit crops:crop improvement and varietal wealt, Jaya Publishing House, Delhi. 2014;392-402.

6. Wani RA, Prasad VM, Hakeem SA, Sheema S, Angchuk S, Dixit A. Shelf life of karonda jams (Carissa carandas L.) under ambient temperature. African Journal of Agricultural Research. https://doi.org/10.5897/AJAR2013.6854

2013;8:2447-49

7. Sueprasarn J, Reabroy S, Pirak T. Antioxidant properties of karanda (Carissa carandas Linn.) extracts and its application in Thai traditional fermented pork sausage (Nham). International Food Research Journal. 2017;24:1667-75.

8. Pewlong W, Sajjabut S, Eamsiri J, Chookaew S. Evaluation of antioxidant activities, anthocyanins, total phenolic content, vitamin c content and cytotoxicity of Carissa carandas Linn. Chiang Mai University Journal of Natural Sciences. 2014;13 509-17. https://doi.org/10.12982/CMUJNS.2014.0053

9. Itankar PR, Lokhande SJ, Verma PR, Arora SK, Sahu RA, Patil AT. Antidiabetic potential of unripe Carissa carandas Linn fruit extract. Journal of Ethnopharmacology. 2011;135:430-33. https://doi.org/10.1016/j.jep.2011.03.036

10. Agarwal $\mathrm{T}$, Singh $\mathrm{R}$, Shukla A, Waris I. In vitro study of antibacterial activity of Carissa carandas leaf extracts. Asian Journal of Plant Science and Research. 2012;2:36-40. https://imedpub.com/articles/in-vitro-study-of-antibacterialactivity-of-carissa-carandas-leaf-extracts.pdf

11. Hegde K, Joshi AB. Hepatoprotective effect of Carissa carandas Linn. root extract against $\mathrm{CCl} 4$ and paracetamol induced hepatic oxidative stress. Indian Journal of Experimental Biology. 2009;47:660-67.

12. Bhaskar $\mathrm{VH}$ and Balakrishnan N. Analgesic, anti-inflammatory and antipyretic activities of Pergularia daemia and Carissa carandas. DARU Journal of Pharmaceutical Sciences. 2009;17:168-74 
13. Fatima A, Singh PP, Agarwal P, Irchhaiya R, Alok S, Verma A. Treatment of various diseases by Carissa spinarum L.: a promising shrub. International Journal of Pharmaceutical Sciences and Research. 2013;4:2489-95. http://dx.doi.org/10.13040/IJPSR.0975-8232.4(7).1000-03

14. Huan PT, Hong NTM. Polyphenol content and antioxidant capacity of herbal tea from Vietnamese water hyssop (Bacopa monnieri). International Journal on Advanced Science, Engineering and Information Technology. 2016;6:61-68. https://doi.org/10.18517/ijaseit.6.1.649

15. Le TT, Phan TH, Raes K. Establishment of a processing procedure for manufacturing dried dragon fruit. Journal of Agricultural Sciences and Technology. 2017;6:32-38.

16. Huan PT, Hien NM, Anh NHT. Optimization of alcoholic fermentation of dragon fruit juice using response surface methodology. Food Research. 2020;4:1529-36. https://doi.org/10.26656/fr.2017.4(5).125

17. Mei-Ling W, Youk-Meng C, Nan-Wei S, Min-Hsiung L. A rapid method for determination of ethanol in alcoholic beverages using capillary gas chromatography. Journal of Food and Drug Analysis. 2003;11:133-40. https://doi.org/10.38212/22246614.2710

18. Singleton VL, Rossi JAJR. Colorimetry of total phenolics with phosphomolybdicphosphotungstic acid reagents. American Journal of Enology and Viticulture. 1965;16:144-58.

19. Abhishek M, Devarajan T. Process optimization, physicochemical characterization and antioxidant potential of novel wine from an underutilized fruit Carissa spinarum L. (Apocynaceae). Food Science and Technology. 2017;9:1-6. http://dx.doi.org/10.1590/1678-457X.06417

20. Kumar YS, Prakasam RS, Reddy OVS. Optimisation of fermentation conditions for mango (Mangifera indica L.) wine production by employing response surface methodology. International Journal of Food Science and Technology. 2009;44:2320-27. http://dx.doi.org/10.1111/j.13652621.2009.02076.x

21. Sevda SB, Rodrigues L. Fermentative behavior of Saccharomyces strains during Guava (Psidium guajava L.) must fermentation and optimization of Guava wine production. Journal of Food Processing and Technology. 2011;2:2-9.

22. Rumjuankiat K, Sonhom N, Showpanish K, Somsri A, Pilasombut $\mathrm{K}$. In vitro antioxidant activities and volatile compounds from karanda (Carissa carandas L.) fruit wine. International Journal of Agricultural Technology. 2018;14:1843-60.

23. Miljic UD and Puskas VS. Influence of fermentation conditions on production of plum (Prunus domestica L.) wine: A response surface methodology approach. Hemijska Industrija. 2014;68:199-206.

http://dx.doi.org/10.2298/HEMIND130307044M
24. Cheng NG, Hasan M, Kumoro AC, Ling CF, Tham M. Production of ethanol by fed-batch fermentation. Pertanika Journal of Science and Technology. 2009;17:399-408.

25. Gavimath CC, Kalsekar DP, Raorane CJ, Kulkarni SM, Gavade BG, Ravishankar BE, Hooli VR. Comparative analysis of wine from different fruits. International Journal of Advanced Biotechnology and Research. 2012;3:810-13. https://bipublication.com/files/IJABR-V3I4-2012-12.pdf

26. Chauhan A, Tanwar B, Arneja I. Influence of processing on physiochemical, nutritional and phytochemical composition of Carissa spinarum (Karonda) fruit. Asian Journal of Pharmaceutical and Clinical Research. 2015;8:254-59. https://innovareacademics.in/journals/index.php/ajpcr/article/ view/8864

27. Marquez A, Serratosa MP, Lopez-Toledano A., Merida J. Colour and phenolic compounds in sweet red wines from Merlot and Tempranillo grapes chamber-dried under controlled conditions. Food Chemistry. 2012;130:111-20. https:// doi.org/10.1016/j.foodchem.2011.07.010

28. Stanley D, Bandara A, Fraser S, Chambers PJ, Stanley GA. The ethanol stress response and ethanol tolerance of Saccharomyces cerevisiae. Journal of Applied Microbiology. 2010;109:13-24. 2672.2009.04657.x https://doi.org/10.1111/j.1365

9. Jagtap UB, Bapat VA. Phenolic composition and antioxidant capacity of wine prepared from custard apple (Annona squamosa L.) fruits. Journal of Food Processing and Preservation. 2015;39:175-82. https://doi.org/10.1111/jfpp.12219

30. Shahidi F. Nutraceuticals and functional foods: whole versus processed foods. Trends in Food Science and Technology. 2009;20:376-87. https://doi.org/10.1016/j.tifs.2008.08.004

\section{Additional information}

Peer review information: Plant Science Today thanks Sectional Editor and the other anonymous reviewers for their contribution to the peer review of this work.

Reprints and permissions information is available at https://horizonepublishing.com/journals/index.php/PST/open_access_policy

Publisher's Note: Horizon e-Publishing Group remains neutral with regard to jurisdictional claims in published maps and institutional affiliations.

To cite this article: Minh N P. Possibility of wine production from karanda (Carissa carandas L.) fruit. Plant Science Today. 2021;8(3):699-703. https://doi.org/10.14719/pst.2021.8.3.1293

Plant Science Today, published by Horizon e-Publishing Group, is covered by Scopus, Web of Science, BIOSIS Previews, Clarivate Analytics, etc. See https://horizonepublishing.com/journals/index.php/PST/indexing_abstracting 